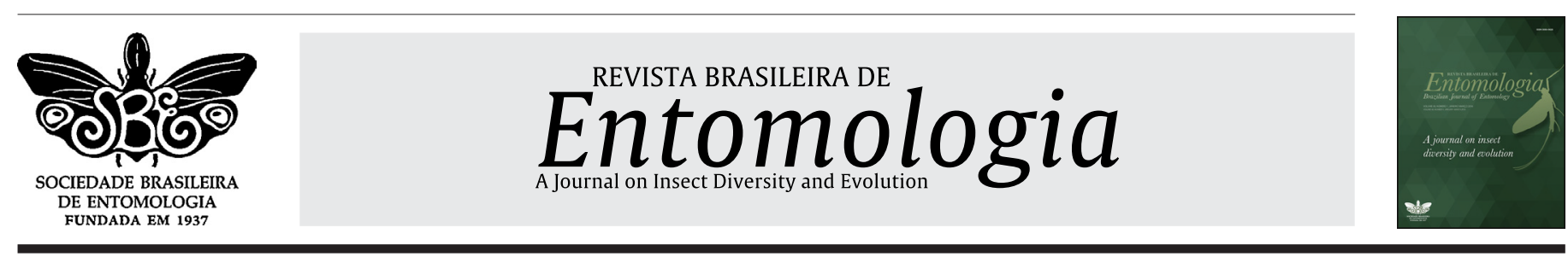

\title{
Antibiosis in soybean genotypes to Spodoptera cosmioides (Lepidoptera: Noctuidae)
}

\author{
Erielma Borges de Queiroz ${ }^{1}$, Débora de Souza Miranda ${ }^{2}$, Franciele Cristina da Silva², \\ Célio Borella Junior ${ }^{2}$, André Cirilo de Sousa Almeida², Edson Hirose ${ }^{3}$, Flávio Gonçalves de Jesus ${ }^{2 *}$
}

${ }^{1}$ Universidade Estadual de Goiás, Campus de Ipameri, Ipameri, GO, Brasil.

Instituto Federal de Educação Ciência e Tecnologia Goiano, Campus Urutaí, Urutaí, GO, Brasil.

${ }^{3}$ Embrapa Soja, Londrina, PR, Brasil.

\section{A R T I C L E I N F O}

Article history:

Received 31 January 2020

Accepted 27 April 2020

Available online 29 June 2020

Associate Editor: Regiane Cristina Bueno

\section{Keyword:}

Glycine max.

Black caterpillar.

Plant resistance to insects.

\begin{abstract}
A B S T R A C T
The occurrence of the black caterpillar Spodoptera cosmioides (Lepidoptera: Noctuidae) has been increasing in soybean crops in Brazil leading to yield losses. The objective of this study was to evaluate antibiosis in soybean genotypes to $S$. cosmioides. The following parameters were evaluated: duration, viability and larval weight; duration and viability of the pre-pupal; duration, weight and viability of pupa; total cycle and sex ratio. The design was completely randomized with 18 treatments (genotypes) and 30 replicates. The genotypes PI 227687, PI227682, IAC 100 and BRS 7270 IPRO showed significant levels of antibiosis against $S$. cosmioides. These results will be useful for soybean producer or in breeding programs focusing on host plant resistance.
\end{abstract}

\section{Introduction}

The soybean (Glycine max) has great relevance for the Brazilian economy and stands out as the main agricultural product for the country's exports (Follmann et al., 2017). Among the pests that attack the soybean crop, the complex of caterpillars are important and frequently cause economic loss (Lourenção et al., 2010; Bueno et al., 2011; Hoffmann-Campo et al., 2012). Spodoptera cosmioides (Lepidoptera: Noctuidae) has been found in soybean plants, reducing leaf area (Freitas et al., 2018) and feeding on pods (Silva et al., 2014; Boiça Júnior et al., 2015).

The occurrence of pest has increased in soybean crops in Brazil with the contributing factors being: crop succession presenting food supply for the insect, successive applications of fungicides and insecticides, abundance of host plants and expansion of cultivated areas (Santos et al., 2005, 2009; Souza et al., 2014a).

The control of caterpillars by entomopathogens, predators and parasitoids was important, and kept the pest population below control levels (Sosa-Gómez et al., 2010). However, with current agricultural practices, chemical control is the most common method, and insecticides have been unsatisfactory (Constanski et al., 2016). In addition, there are relatively few products registered for control of $S$. cosmioides

\footnotetext{
* Corresponding author.

E-mail: flavio.jesus@ifgoiano.edu.br (F.G. Jesus)
}

in Brazil (Agrofit, 2020) and soybean plants with Bt gene insertion (Bacillus thuringiensis - Bacillacea) are inefficient to control Spodoptera (Bortolotto et al., 2016; Horikoshi et al., 2016). Thus, the study of methods compatible with IPM, that can reduce the use of insecticides are necessary (Sosa-Gómez and Silva, 2010; Constanski et al., 2016).

Plant resistance to insects - PRI, is expressed through different mechanisms such as: antixenosis (non-preference), antibiosis and tolerance. Antixenosis is associated with the presence of trichomes, changes in leaf color or the presence of volatile compounds in the plant (Smith, 2005; Seifi et al., 2013). Antibiosis is manifested mainly by chemical constituents present in the plant and affects the biology and/or physiology of the pest, such as: reduction in larval and pupal weight, prolongation of life cycle, adult deformation, alteration in sex ratio (Souza et al., 2014b; Boiça Júnior et al., 2015; Almeida et al., 2017) and tolerance, which is the ability of the plant to resist or recover from insect damage due to the production of new vegetative or reproductive structures (Smith, 2005; Seifi et al., 2013). RPI is considered an ideal control method because it maintains pest population density below the economic injury level, has no adverse effect on the environment, requires no additional expenses, can be combined with other control tactics, is compatible with IPM and can be used directly by farmers (War et al., 2012; Seifi et al., 2013). 
Soybean plants have defense mechanisms that manifest resistance against pests due to morphological characteristics, such as trichome density, plant coloring (Souza et al., 2014c; Prado et al., 2016) and chemical compounds such as flavonoids (Hoffmann-Campo et al., 2001; Piubelli et al., 2005; Silva et al., 2013, 2014; Timbó et al., 2014). The use of resistant plants against lepidoptera in soybean cultivation has been studied, but few studies have involved $S$. cosmioides. Souza et al. (2014b) observed antibiosis to S. eridania in the genotypes PI 227687 and PI 227682 and Boiça Júnior et al. (2015) in PI 227682, PI 227687 and IAC 100. Souza et al. (2014c) and Piubelli et al. (2005) showed antibiosis to Chrysodeixis includens (Lepidoptera: Noctuidae) and Anticarsia gemmatalis (Lepidoptera: Erebidae) in IAC 100 and Almeida et al. (2017) found antibiosis in IAC 100 and M 7110 IPRO to Chloridea virescens (Lepidoptera: Noctuidae).

The present study aimed to evaluate antibiosis to $S$. cosmioides in different soybean genotypes (commercial cultivars and genotypes).

\section{Material and methods}

Experiments were carried out at the laboratory of Integrated Pest Management of Federal Goiano Institute, Campus Urutaí, Goiás, Brazil. Laboratory assays were conducted under controlled conditions of temperature $\left(25^{\circ} \mathrm{C} \pm 2\right)$, relative humidity $(70 \% \pm 10)$ and photoperiod (12h).

\section{Spodoptera cosmioides rearing}

A Spodoptera cosmioides colony was established from larvae provided by the São Paulo State University (UNESP), laboratory of Plant Resistance to Insects in Jaboticabal, São Paulo, Brazil. The larvae were fed with artificial diet (Greene et al., 1976) and raised in plastic pots $(300 \mathrm{~mL})$ in a group of four larvae up to the pupal stage. The pupas were sexed and placed in a PVC cage ( $20 \mathrm{~cm}$ Height $\mathrm{x} 20 \mathrm{~cm}$ in diameter) for emergence and mating of adults.

The adults were fed on $10 \%$ honey solution and the diet was changed every two days. Ovipositions were removed daily and placed in plastic pots $(500 \mathrm{~mL})$ until larva hatching.

\section{Plant material}

The genotypes used in the studies were obtained from the soybean breeding program at the Brazilian Agricultural Research Corporation - EMBRAPA, National Soybean Research Center (Londrina, Parana, Brazil) (Table 1).

Plants were grown in 5L pots filled with substrate (3:1:1 - soil, sand and organic bovine manure) and fertilized according crop requirements (Sousa and Lobato, 2004). The soybean plants were kept in the greenhouse under environmental conditions and irrigated daily using the same volume of water per pot to avoid water stress. Soybean plants were used in the assays 30 days after sowing.

\section{Antibiosis in soybean genotypes to Spodoptera cosmioides}

Newly hatched $S$. cosmioides larvae were individualized in plastic containers $(100 \mathrm{~mL})$ containing moistened filter paper and fed with leaves from soybean genotypes. The larvae remained in the plastic container until the pupal stage when feeding was interrupted. The emerged adults were individualized and caged to measure the longevity and food was not provided for the insect. The following biological parameters were evaluated: a) larval: duration and viability of the larval stage and weight of larvae at ten days; b) pre-pupal: duration and viability; c) pupal: duration, weight of pupa at 24 hours and viability; d) adult: longevity and e) total cycle: period and viability and sex ratio. A completely randomized design with 18 treatments (genotypes) and 30 replicates was adopted. Each repetition was considered to be an individualized larva in the plastic container.

\section{Statistical analysis}

The results were submitted to multivariate analysis of variance (MANOVA). There was a significant effect $(P<0.05)$ of genotypes when the means were compared by the Scott Knott test at 5\% probability (R Development Core Team, 2017, Scott Knott Package). A cluster analysis was performed using the Hierarchical Cluster Analysis - UPGMA method based on the Mahalanobis generalized distance to group cultivars by their level of resistance (R Development Core Team, 2017, Biotools

Table 1

Name and agronomic characteristics of soybean genotypes

\begin{tabular}{|c|c|c|c|c|c|}
\hline Genotypes & Growth habitat & Maturity group & Transgenic & ${ }^{5} \mathrm{NRC}$ & Origin \\
\hline Anta $82^{1}$ & Semi-determinate & 7.4 & ${ }^{3} \mathrm{RR}$ & 24879 & Brazil \\
\hline BMX Desafio $^{1}$ & Indeterminate & 7.3 & $\mathrm{RR}$ & 28779 & Brazil \\
\hline BMX Potência $^{1}$ & Indeterminate & 6.6 & $\mathrm{RR}$ & 22332 & Brazil \\
\hline BRS $397^{1}$ & Indeterminate & 6.2 & ${ }^{4} \mathrm{CV}$ & 33356 & Brazil \\
\hline BRS 6970 IPRO $^{1}$ & Indeterminate & 6.9 & IPRO & 33068 & Brazil \\
\hline BRS 7270 IPRO $^{1}$ & Indeterminate & 7.2 & IPRO & 33066 & Brazil \\
\hline BRS 7470 IPRO $^{1}$ & Indeterminate & 7.4 & IPRO & 33065 & Brazil \\
\hline BRS 8170 IPRO $^{1}$ & Indeterminate & 8.1 & IPRO & 35275 & Brazil \\
\hline BRS $8482^{1}$ & Determinate & 8.0 & $\mathrm{CV}$ & 34078 & Brazil \\
\hline BRS GO $7460^{1}$ & Determinate & 7.4 & $\mathrm{RR}$ & 28063 & Brazil \\
\hline BRS GO Jataí1 & Determinate & 8.9 & $\mathrm{CV}$ & 01179 & Brazil \\
\hline IAC $100^{1}$ & Indeterminate & 8.1 & $\mathrm{CV}$ & 01190 & Brazil \\
\hline M 7739 IPRO $^{1}$ & Semi-determinate & 7.7 & IPRO & 29692 & Brazil \\
\hline NA $5909^{1}$ & Indeterminate & 6.9 & $\mathrm{RR}$ & 24590 & Brazil \\
\hline NS 7338 IPRO $^{1}$ & Indeterminate & 7.3 & IPRO & 29474 & Brazil \\
\hline NS 7447 IPRO ${ }^{1}$ & Indeterminate & 7.4 & IPRO & 33001 & Brazil \\
\hline PI $227682^{2}$ & - & - & $\mathrm{CV}$ & - & Japão \\
\hline PI $227687^{2}$ & - & - & $\mathrm{CV}$ & - & Japão \\
\hline
\end{tabular}

${ }^{1}$ Commercial cultivar. ${ }^{2}$ Breeding line. ${ }^{3}$ RR: Roundup ready. ${ }^{4} \mathrm{CV}$ : Conventional. ${ }^{5}$ National register of cultivars. 
package). A Canonical Discriminant Analysis -- CVA was performed to study the distance relationship between genotypes, as well as their relationship with the resistance variables (R Development Core Team, 2017, Candisc package) to determine the degree of resistance between the soybean genotypes to $S$. cosmioides.

\section{Results}

The growth of $S$. cosmioides was influenced by the soybean genotypes (Table 2 ). The larval period ( $\mathrm{F}=7.32 \mathrm{df}=17, \mathrm{P}<0.0001)$ of S. cosmioides was higher in IAC 100 and BRS 7270 IPRO and lower in NA 5909, BRS 8482 NS 7447 IPRO and BRS GO 7460. The lowest larval viability ( $\mathrm{F}=8.12, \mathrm{df}=17, \mathrm{P}<0.0001)$ was in BMX Desafio, BRS GO 7460, NA 5909, PI227682 and PI227687 while the highest was observed with BRS 6970 IPRO, BRS 7470 IPRO and BRS 8482.
The pre-pupal period ( $\mathrm{F}=3.46, \mathrm{df}=17, \mathrm{P}<0.0001)$ of $S$. cosmioides fed on PI 227687 was higher, except in IAC 100, PI 227682, NS 7447, BMX Desafio and M 7739 IPRO, which presented intermediate values. The pupal period ( $\mathrm{F}=1.77, \mathrm{df}=17, \mathrm{P}=0.0360$ ) was highest in PI 227687 and the other cultivars did not influence this biological parameter. The pupal viability $(\mathrm{F}=7.23$, $\mathrm{df}=17 ; \mathrm{P}<0.0001)$ was lowest in BMX Desafio, PI 227687, NS 7447 IPRO, PI 227682, NA 5909, BRS 7270 IPRO and IAC 100, while the highest were in BRS 6970 IPRO and BRS 7470 IPRO.

The larval weight $(\mathrm{F}=9.90, \mathrm{df}=17, \mathrm{P}<0.0001)$ and pupal weight $(\mathrm{F}=1.89, \mathrm{df}=17, \mathrm{P}=0.0223)$, adult longevity $(\mathrm{F}=2.62, \mathrm{df}=17, \mathrm{P}=0.0119)$, life cycle $(\mathrm{F}=3.61, \mathrm{df}=17, \mathrm{P}<0.0001)$ and total viability $(\mathrm{F}=4.39$, $\mathrm{df}=17 ; \mathrm{P}<0.0001)$ of $S$. cosmioides were influenced by the soybean genotypes (Table 3 ).

The cultivars BRS 7470 IPRO and ANTA 82 RR presented the highest larval weight. The genotypes IAC 100, BRS G0 7460, BMX Desafio, NA 5909,

Table 2

Means and standard error of Larval period - days, Larval viability - \%, Pre-pupal period - days, Pupal period - days, and Pupal viability - \% in soybean genotypes for resistance to Spodoptera cosmioides (Lepidoptera: Noctuidae). Urutaí, Goiás, Brazil

\begin{tabular}{|c|c|c|c|c|c|}
\hline Genotypes & Larval period & Larval viability & Pre-pupal period & Pupal period & Pupal viability \\
\hline Anta 82 & $26.80 \pm 0.97 c$ & $50.00 \pm 9.28 \mathrm{~b}$ & $2.00 \pm 0.40 \mathrm{c}$ & $14.40 \pm 1.12 \mathrm{~b}$ & $36.67 \pm 8.95 \mathrm{~b}$ \\
\hline BMX Desafio & $29.00 \pm 0.56 b$ & -2 & $4.00 \pm 0.05 b$ & $11.00 \pm 0.26 b$ & -2 \\
\hline BMX Potência & $29.33 \pm 1.87 \mathrm{~b}$ & $40.00 \pm 9.10 \mathrm{c}$ & $2.17 \pm 0.20 \mathrm{c}$ & $14.83 \pm 0.70 \mathrm{~b}$ & $40.00 \pm 9.10 \mathrm{~b}$ \\
\hline BRS 397 & $31.00 \pm 1.62 \mathrm{~b}$ & $37.93 \pm 9.17 \mathrm{c}$ & $2.57 \pm 0.19 \mathrm{c}$ & $14.57 \pm 0.75 \mathrm{~b}$ & $34.48 \pm 8.98 \mathrm{~b}$ \\
\hline BRS 6970 IPRO & $28.18 \pm 0.71 \mathrm{c}$ & $80.00 \pm 7.43 \mathrm{a}$ & $2.47 \pm 0.67 c$ & $15.00 \pm 0.41 \mathrm{~b}$ & $83.33 \pm 6.92 \mathrm{a}$ \\
\hline BRS 7270 IPRO & $34.00 \pm 1.00 \mathrm{a}$ & $43.33 \pm 9.20 c$ & $2.67 \pm 0.27 \mathrm{c}$ & $14.00 \pm 0.58 \mathrm{~b}$ & $20.00 \pm 7.43 c$ \\
\hline BRS 7470 IPRO & $28.69 \pm 1.24 \mathrm{c}$ & $80.00 \pm 7.43 \mathrm{a}$ & $2.54 \pm 0.25 c$ & $15.46 \pm 0.69 \mathrm{~b}$ & $63.33 \pm 8.95 \mathrm{a}$ \\
\hline BRS 8170 IPRO & $31.50 \pm 1.48 b$ & $63.33 \pm 8.21 b$ & $2.25 \pm 0.34 \mathrm{c}$ & $14.62 \pm 0.73 \mathrm{~b}$ & $53.33 \pm 9.26 b$ \\
\hline BRS 8482 & $27.14 \pm 0.74 \mathrm{~d}$ & $73.33 \pm 8.95 \mathrm{a}$ & $2.14 \pm 0.24 \mathrm{c}$ & $15.86 \pm 0.88 b$ & $40.00 \pm 9.10 \mathrm{~b}$ \\
\hline BRS GO 7460 & $27.80 \pm 2.06 \mathrm{~d}$ & $20.00 \pm 7.43 \mathrm{~d}$ & $2.60 \pm 0.49 c$ & $14.20 \pm 0.58 \mathrm{~b}$ & $16.67 \pm 6.92 \mathrm{c}$ \\
\hline BRS GO Jataí & $28.60 \pm 2.09 \mathrm{c}$ & $56.67 \pm 9.20 \mathrm{~b}$ & $2.20 \pm 0.00 \mathrm{c}$ & $12.20 \pm 0.20 \mathrm{~b}$ & $46.67 \pm 9.26 \mathrm{~b}$ \\
\hline IAC 100 & $36.00 \pm 1.00 \mathrm{a}$ & $30.00 \pm 8.52 \mathrm{c}$ & $4.00 \pm 0.33 \mathrm{~b}$ & $14.50 \pm 0.50 \mathrm{~b}$ & $23.33 \pm 7.85 \mathrm{c}$ \\
\hline M 7739 IPRO & $31.00 \pm 3.06 \mathrm{~b}$ & $53.33 \pm 9.26 \mathrm{~b}$ & $2.67 \pm 0.33 c$ & $14.00 \pm 1.00 \mathrm{~b}$ & $40.00 \pm 9.10 \mathrm{~b}$ \\
\hline NA 5909 & $26.00 \pm 2.31 \mathrm{~d}$ & $23.33 \pm 7.85 \mathrm{~d}$ & $2.67 \pm 0.17 c$ & $14.67 \pm 1.45 \mathrm{~b}$ & $16.67 \pm 6.92 \mathrm{c}$ \\
\hline NS 7338 IPRO & $29.17 \pm 1.78 \mathrm{~b}$ & $36.67 \pm 8.95 \mathrm{c}$ & $2.83 \pm 0.33 c$ & $14.17 \pm 1.01 \mathrm{~b}$ & $33.33 \pm 8.75 \mathrm{~b}$ \\
\hline NS 7447 IPRO & $27.67 \pm 0.88 \mathrm{~d}$ & $30.00 \pm 8.51 \mathrm{c}$ & $3.67 \pm 0.33 b$ & $13.33 \pm 1.86 b$ & $13.33 \pm 6.31 \mathrm{c}$ \\
\hline PI 227682 & $31.00 \pm 1.00 \mathrm{~b}$ & $20.00 \pm 7.43 \mathrm{~d}$ & $3.33 \pm 0.33 c$ & $15.00 \pm 1.73 \mathrm{~b}$ & $13.33 \pm 6.31 \mathrm{c}$ \\
\hline PI 227687 & $28.00 \pm 0.38 c$ & -2 & $5.00 \pm 0.10 a$ & $25.00 \pm 0.59 \mathrm{a}$ & -2 \\
\hline
\end{tabular}

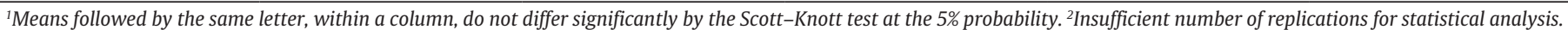

Table 3

Means and standard error of Larval weight - mg, Pupal weight - mg, Adult longevity - days, Life cycle - days, Total viability - \% and Sex ratio - female/male in soybean genotypes for resistance to Spodoptera cosmioides (Lepidoptera: Noctuidae). Urutaí, Goiás, Brazil

\begin{tabular}{|c|c|c|c|c|c|c|}
\hline Genotypes & Larval weight & Pupal weight & Adult longevity & Life cycle & Total viability & Sex ratio \\
\hline Anta 82 & $1.20 \pm 0.13 \mathrm{a}$ & $0.25 \pm 0.03 \mathrm{~b}$ & $1.60 \pm 0.40 \mathrm{~b}$ & $44.80 \pm 1.83 \mathrm{c}$ & $16.67 \pm 6.92 \mathrm{c}$ & 0.43 \\
\hline BMX Desafio & $0.62 \pm 0.01 \mathrm{c}$ & $0.33 \pm 0.01 \mathrm{a}$ & $2.00 \pm 0.05 \mathrm{~b}$ & $46.00 \pm 1.08 \mathrm{c}$ & $3.33 \pm 3.33 c$ & 0.61 \\
\hline BMX Potência & $0.75 \pm 0.17 \mathrm{c}$ & $0.32 \pm 0.02 \mathrm{a}$ & $1.67 \pm 033 \mathrm{~b}$ & $48.00 \pm 1.51 \mathrm{~b}$ & $23.33 \pm 7.85$ c & 0.37 \\
\hline BRS 397 & $0.75 \pm 0.19 c$ & $0.31 \pm 0.02 a$ & $3.14 \pm 0.26 a$ & $51.29 \pm 1.17 \mathrm{~b}$ & $27.59 \pm 8.45 b$ & 0.51 \\
\hline BRS 6970 IPRO & $0.97 \pm 0.08 \mathrm{~b}$ & $0.29 \pm 0.01 \mathrm{a}$ & $3.24 \pm 0.25 \mathrm{a}$ & $48.88 \pm 0.68 \mathrm{~b}$ & $56.67 \pm 9.20 \mathrm{a}$ & 0.48 \\
\hline BRS 7270 IPRO & $0.82 \pm 0.26 b$ & $0.26 \pm 0.01 \mathrm{a}$ & $1.33 \pm 0.33 b$ & $52.00 \pm 1.00 \mathrm{~b}$ & $6.67 \pm 4.63 c$ & 0.52 \\
\hline BRS 7470 IPRO & $1.28 \pm 0.10 \mathrm{a}$ & $0.29 \pm 0.01 \mathrm{a}$ & $2.00 \pm 0.20 \mathrm{~b}$ & $48.69 \pm 0.64 b$ & $43.33 \pm 9.20 \mathrm{a}$ & 0.58 \\
\hline BRS 8170 IPRO & $0.78 \pm 0.14 b$ & $0.28 \pm 0.01 \mathrm{a}$ & $2.00 \pm 0.27 b$ & $50.38 \pm 0.92 b$ & $30.00 \pm 8.51 \mathrm{~b}$ & 0.65 \\
\hline BRS 8482 & $1.09 \pm 0.18 b$ & $0.26 \pm 0.02 \mathrm{a}$ & $3.29 \pm 0.47 \mathrm{a}$ & $48.43 \pm 0.69 \mathrm{~b}$ & $23.33 \pm 7.85$ c & 0.65 \\
\hline BRS GO 7460 & $0.53 \pm 0.19 \mathrm{c}$ & $0.29 \pm 0.02 \mathrm{a}$ & $1.80 \pm 0.37 \mathrm{~b}$ & $46.40 \pm 2.11 c$ & $16.67 \pm 6.92 \mathrm{c}$ & 0.61 \\
\hline BRS GO Jataí & $0.98 \pm 0.20 c$ & $0.31 \pm 0.04 \mathrm{a}$ & $3.20 \pm 0.37 a$ & $46.20 \pm 2.35 c$ & $16.67 \pm 6.92 \mathrm{c}$ & 0.41 \\
\hline IAC 100 & $0.46 \pm 0.10 c$ & $0.29 \pm 0.01 \mathrm{a}$ & $2.00 \pm 1.00 \mathrm{~b}$ & $57.50 \pm 0.50 \mathrm{a}$ & $6.67 \pm 4.63 c$ & 0.29 \\
\hline M 7739 IPRO & $0.86 \pm 0.20 c$ & $0.25 \pm 0.02 \mathrm{~b}$ & $2.67 \pm 0.33 \mathrm{a}$ & $50.33 \pm 1.67 \mathrm{~b}$ & $10.00 \pm 5.57 \mathrm{c}$ & 0.54 \\
\hline NA 5909 & $0.69 \pm 0.33 c$ & $0.26 \pm 0.01 \mathrm{a}$ & $2.67 \pm 0.33 \mathrm{a}$ & $46.00 \pm 3.21 c$ & $10.00 \pm 5.57 \mathrm{c}$ & 0.61 \\
\hline NS 7338 IPRO & $1.01 \pm 0.05 \mathrm{~b}$ & $0.23 \pm 0.01 \mathrm{a}$ & $2.33 \pm 0.80 \mathrm{~b}$ & $48.50 \pm 0.85 b$ & $16.67 \pm 6.92 \mathrm{c}$ & 0.55 \\
\hline NS 7447 IPRO & $1.09 \pm 0.41 \mathrm{~b}$ & $0.26 \pm 0.04 \mathrm{a}$ & $1.33 \pm 0.33 \mathrm{~b}$ & $46.00 \pm 1.00 \mathrm{c}$ & $10.00 \pm 5.57 \mathrm{c}$ & 0.61 \\
\hline PI 227682 & $0.74 \pm 0.04 \mathrm{c}$ & $0.24 \pm 0.03 b$ & $2.33 \pm 1.33 b$ & $51.67 \pm 2.03 \mathrm{~b}$ & $10.00 \pm 5.57 \mathrm{c}$ & 0.35 \\
\hline PI 227687 & $1.07 \pm 0.09 \mathrm{~b}$ & $0.18 \pm 0.01 \mathrm{c}$ & $1.00 \pm 0.02 \mathrm{~b}$ & $59.00 \pm 1.40 \mathrm{a}$ & -2 & 0.59 \\
\hline
\end{tabular}

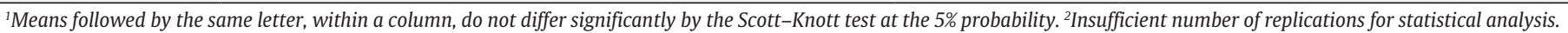


PI 227682, BMX Potência, BRS 397, M 7739 IPRO and BRS GO Jataí showed lowest larval weight. PI 227687 showed the lowest S. cosmioides pupal weight, while the others had the highest values, except for ANTA 82 and M 7739 IPRO. The adults from BRS 397, BRS 6970 IPRO, BRS 8482, M 7739 IPRO and NA 5909 were longer than the others. The insects from PI 227687 and IAC 100 presented a prolonged life cycle, while, Anta 82 RR, NS 7447 IPRO, NA 5909, BMX Desafio, BRS GO 7460 and BRS GO Jataí presented a shorter life cycle. The total viability was highest in BRS 6970 IPRO and BRS 7470 IPRO. The other cultivars showed the lowest total viability, except for BRS 397 and BRS 8170 IPRO, which presented intermediate values. The sex ratio of $S$. cosmioides was not influenced by soybean genotypes (Table 3).

By hierarchical grouping analysis - UPGMA was observed the influence of soybean genotypes in the biological parameters of $S$. cosmioides (Fig. 1). Five groups were established according to the level of resistance. Groups I (Anta 82) and II (BMX Desafio and BRS GO Jataí), presented high susceptibility to $S$. cosmioides. Group III (BRS GO 7460, BR 597, BRS 397, BRS 8170 IPRO, BRS 7270 IPRO, NS 7338 IPRO, BRS 7470 IPRO, M 7739 IPRO, PI 227682, BRS 6970 IPRO and BRS 8482) were susceptible. Group IV (IAC 100) presented moderate resistance and group V (PI 227687) showed high resistance to $S$. cosmioides.

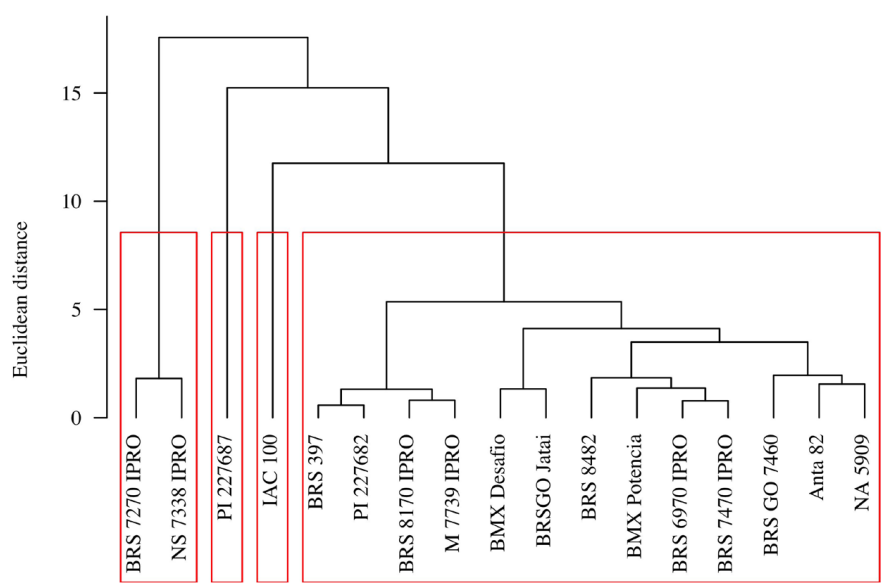

Figure 1 Dendrogram resulting from the multivariate grouping analyses, using the UPGMA method, based on the Mahalanobis distance, from the LP (Larval period - days), PP (Pupal period - days), LW (Larval weight - mg), PW (Pupal weight - mg), LC (Life cycle - days) and TV (Total viability - percentage) in soybean genotypes for resistance to Spodoptera cosmioides (Lepidoptera: Noctuidae). Urutaí, Goiás, Brazil.

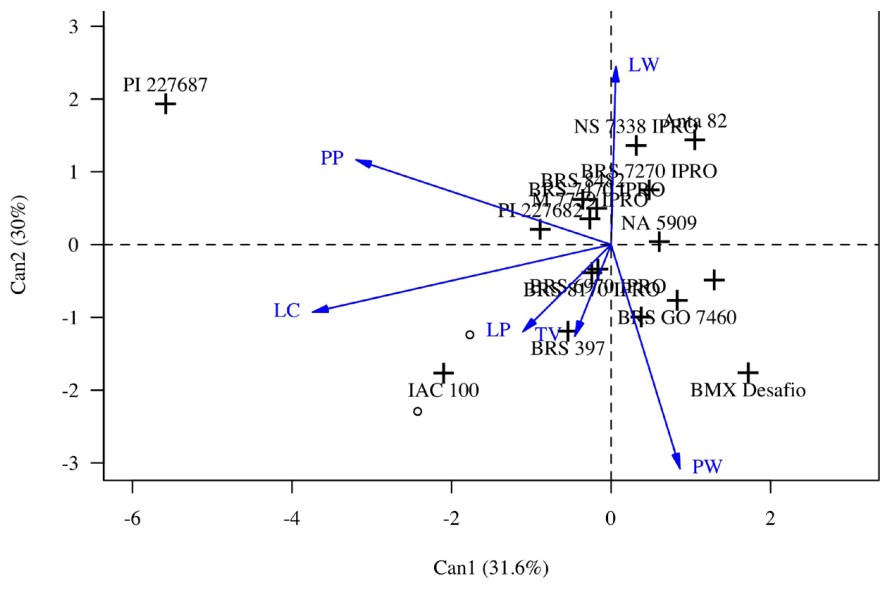

Figure 2 Biplot containing average scores of 18 soybean genotypes for resistance to Spodoptera cosmioides (Lepidoptera: Noctuidae). Evaluated characters: LP(Larval period - days), PP (Pupal period - days), LW (Larval weight - mg), PW (Pupal weight - mg), LC (Life cycle - days).
This was supported by the canonical variable analysis - CVA (Fig. 2). Both multivariate methods provided similar results regarding the resistance groupings. The genotype PI 227687 that appears isolated in the CVA analysis, also appears in group V in the UPGMA, influencing the S. cosmioides pupal period. IAC 100, which appears isolated in the CVA analysis, also appears in group IV in the UPGMA analysis, influencing the total viability and larval weight of $S$. cosmioides. The susceptible cultivar BMX Desafio also appears isolated in CVA analysis and pupal weight was the main characteristic that defined this degree of resistance.

The first canonical variable explained $31.6 \%$ of the total parameters evaluated for the characteristics described in the soybean genotypes and this component was influenced by pupal period and the total cycle. The second component explained $30 \%$ of the variability and was influenced by larval period, total viability, larval weight and pupal weight.

\section{Discussion}

Antibiosis is the category of resistance that occurs when the insect feeds on the plant, negatively affecting the insect's biology. The cause of resistance can be chemical and/or morphological plant defensive factors. The reduction of body size and weight, prolonged periods of development and reduced fecundity are characteristics of antibiosis (Lara, 1991; Smith, 2005; Seifi et al., 2013). The results showed that soybean genotypes influenced the biological parameters and presented different degrees of resistance to $S$. cosmioides.

Genotypes BRS 7270 IPRO, PI 227687 and IAC100 extended the larval period of $S$. cosmioides in relation to BRS 8482, BRS GO 7460, NA 5909 and NS 7447 IPRO. The larval viability was lower in BMX Desafio, BRS GO 7460, NA 5909, PI 227682 and PI 227687. The prolongation of the larval period may be associated with the presence of chemical compounds which confers antibiosis and/or antixenosis (Silveira et al., 1997; Boiça Júnior et al., 2015). Defenses in plant resistance results from physical tissue strength, structural barriers (trichomes), presence of allelochemicals such as alkaloids, ketones, glucosinolates, isoflavonoids, terpenoids and organic acids (War et al., 2012).

The pupal period of $S$. cosmioides was also affected by soybean genotypes. The longest period was observed in pupae from PI 227687 and the lowest viability in BMX Desafio, BRS 7270 IPRO, BRS GO 7460, IAC 100, NA 5909, NS 7447 IPRO and PI 227682 and PI 227687. The chronic effects of antibiosis often cause larval and pupal mortality (Smith, 2005). S. cosmioides fed on IAC 100, PI 227682 and PI 227687 did not reach the pupal stage (Boiça Júnior et al., 2015). This finding characterizes antibiosis in these soybean genotypes to $S$. cosmioides.

The lowest larval weight of $S$. cosmioides was observed on BMX Desafio, BMX Potência, BRS 397, BRS GO 7460, BRS GO Jataí, IAC 100, M 7739 IPRO, NA 5909 and PI 227682. This lower weight may be due the presence of secondary metabolites present in these genotypes. The flavonoids (rutin and genistin) were identified in PI 274454, PI 227687, and IAC-100 genotypes, and these substances play a defense role in soybean plants and are deterrents, conferring resistance to insects (Piubelli et al., 2005). The flavonoid rutin prolonged the larval period, reduced the larval and pupal weight and decreased the pupal viability of $S$. frugiperda (Silva et al., 2016).

Genotypes IAC 100 and PI 227682 have been reported to negatively affect insect biology. Boiça Júnior et al. (2015) found that PI227682 and IAC100 reduced the larval weight and viability of $S$. cosmioides. Piubelli et al. (2005) observed larval weight reduction in $A$. gemmatalis fed on plants with leaf extract of IAC 100 and PI 227687.

Larvae fed on PI-227687, IAC 100 and BRS 7270 IPRO had their life cycles extended. Probably these genotypes were not adequate to supply the nutritional demands for $S$. cosmioides. This characteristic is common in insects that have unbalanced feeding or that ingest 
inappropriate metabolites (Panizzi and Parra, 2009). The pest life cycle prolongation is desirable in plant resistance to insects, since the insect will have fewer generations, reducing population density generating a consequent reduction in the damage to agricultural crops (Lara, 1991; Baldin et al., 2019).

Both CVA and UPGMA analyses separated the soybean genotypes into different levels of resistance to $S$. cosmioides and can be used as a complement to univariate methods in selection of plant resistance to insects (Pitta et al., 2010). The least suitable genotypes for $S$. cosmioides were found to be PI 227687, PI 277682 and IAC 100. Thus, the high percentage of mortality in the larval phase can be attributed to the possible effects of secondary metabolites characterizing antibiosis. The cultivar BRS 7270 IPRO can be used by soybean producers in combination with other control tactics in integrated pest management of $S$. cosmioides.

\section{Conclusions}

Genotypes PI 227687, PI 226782, IAC 100 and BRS 7270 IPRO show antibiosis to $S$. cosmioides. The cultivar BRS 7270 IPRO needs to be further evaluated under field conditions to verify the level of resistance to $S$. cosmioides. These results will be useful for soybean producer or in breeding programs focusing on host plant resistance.

\section{Acknowledgments}

The authors would like to thank National Council of Research and Technology of Brazil (CNPq) grant 307029/2019-0. Instituto Federal Goiano - Campus Urutaí. Universidade Estadual de Goiás (UEG) Câmpus Ipameri. Embrapa Rice and Beans (Santo Antônio de Goiás, Goiás, Brazil) for the funds and support in this research.

\section{Conflict of interest}

The authors declare no conflict of interest in this research.

\section{Compliance with ethical standards}

The authors declare that this research did not infringe any compliance

with ethical standards.

\section{Author contribution statement}

This work was carried out in collaboration between the authors. Erielma B. de Queiroz, Débora S. Miranda, Franciele C. da Silva and Célio Borella Junior designed the study, performed the statistical analysis and wrote the first version of the manuscript. André C. S. Almeida, Edson Hirose and Flávio G. de Jesus managed the literature searches and performed the critical analysis. All authors read and approved the final version of the manuscript.

\section{References}

Agrofit, 2020. Base de dados de produtos agrotóxicos e fitossanitários. Secretaria de Defesa Agropecuária, Ministério da Agricultura e do Abastecimento, Brasília. Available in: http://agrofit.agricultura.gov. br/agrofit_cons/principal_agrofit_cons (accessed 24 march 2020).
Almeida, A. C. S., Silva, C. L. T., Paiva, L. A., Araujo, M. S., Jesus, F. G., 2017. Antibiosis in soybean cultivars to Heliothis virescens (Lepidoptera: noctuidae). Fla. Entomol. 100 (2), 334-338. http:// dx.doi.org/10.1653/024.100.0231.

Boiça Júnior, A. L., Bottega, D. B., Souza, B. H. S., Rodrigues, N. E. L., Michelin, V., 2015. Determination of the resistance types to Spodoptera cosmioides (Walker) (Lepidoptera: Noctuidae) in soybean genotypes. Semina: Ciênc. Agrár. 36 (2), 607-618. http:// dx.doi.org/10.5433/1679-0359.2015v36n2p607.

Baldin, E. L. L., Vendramim, J. D., Lourenção, A. L., 2019. Resistência de plantas a insetos: fundamentos e aplicações. FEALQ Piracicaba, 493pp.

Bortolotto, O. C., Bueno, A. F., Queiroz, A. P., Silva, G. V., 2016. Larval development of Spodoptera eridania and Spodoptera frugiperda fed on fresh ear of field corn expressing the Bt proteins (Cry1F and Cry1F + Cry1A.105 + Cry2Ab2). Cienc. Rural 46 (11), 1898-1901. http://dx.doi.org/10.1590/0103-8478cr20151461.

Bueno, R. C. O. F., Bueno, A. F., Moscardi, F., Parra, J. R. P., HoffmannCampo, C. B., 2011. Lepidopteran larva consumption of soybean foliage: basis for developing multiple-species economic thresholds for pest management decisions. Pest Manag. Sci. 67 (2), 170-174. http://dx.doi.org/10.1002/ps.2047.

Constanski, K. C., Zorzetti, J., Santoro, P. H., Hoshino, A. T., Neves, P. M. O. J., 2016. Inert powders alone or in combination with neem oil for controlling Spodoptera eridania and Spodoptera frugiperda (Lepidoptera: Noctuidae) larvae. Semina: Ciênc. Agrár. 37 (4), 1801-1810. http://dx.doi.org/10.5433/1679-0359.2016v37n4p1801.

Follmann, D. N., Cargnelutti Filho, A., Souza, V. Q., Nardino, M., Carvalho, I. R., Demari, G. H., Ferrari, M., Pelegrin, A. J., Szareski, V. J., 2017. Linear relations among traits in off-season soybean. Rev. Cienc. Agrar. (Lisb.) 40, 213-221. http://dx.doi.org/10.19084/RCA16027.

Freitas, M. M., Souza, B. H. S., Nogueira, L., Di Bello, M. M., Boiça Júnior, A. L., 2018. Soybean defense induction to Spodoptera cosmioides herbivory is dependent on plant genotype and leaf position. Arthropod-Plant Interact. 12 (1), 85-96. http://dx.doi.org/10.1007/ s11829-017-9556-y.

Greene, G. L., Leppla, N. C., Dickerson, W. A., 1976. Velvetbean caterpillar rearing produce and artificial medium. J. Econ. Entomol. 69 (4), 487-488. http://dx.doi.org/10.1093/jee/69.4.487.

Hoffmann-Campo, C. B., Corrêa-Ferreira, B. S., Moscardi, F., 2012. Soja: manejo integrado de insetos e outros artrópodes-praga. Embrapa, Brasília.

Hoffmann-Campo, C. B., Harborne, J. B., McCaffery, A. R., 2001. Preingestive and postin effects of soybean extracts and rutin on Trichoplusia ni growth. Entomol. Exp. Appl. 98 (2), 181-194. http:// dx.doi.org/10.1046/j.1570-7458.2001.00773.x.

Horikoshi, R. J., Bernardi, D., Bernardi, O., Malaquias, J. B., Okuma, D. M., Miraldo, L. L., Amaral, F. S. A., Omoto, C., 2016. Effective dominance of resistance of Spodoptera frugiperda to Bt maize and cotton varieties: implications for resistance management. Sci. Rep. 6 (1), 34864. http://dx.doi.org/10.1038/srep34864.

Lara, F. M. 1991. Princípios de resistência de plantas a insetos. Ícone, São Paulo, 336pp.

Lourenção, A. L., Reco, P. C., Braga, N. R., Valle, G. E., Pinheiro, J. B., 2010. Produtividade de genótipos de soja sob infestação de lagarta-da-soja e de percevejos. Neotrop. Entomol. 39 (2), 275-281. http://dx.doi. org/10.1590/S1519-566X2010000200020.

Panizzi, A. R., Parra, J. R. P., 2009. Bioecologia e nutrição de insetos: base para o manejo integrado de pragas. Embrapa, Brasília, 1164pp.

Pitta, R. M., Boiça Junior, A. L., Jesus, F. G., Tagliari, S. R. A., 2010. Seleção de genótipos resistentes de amendoinzeiro a Anticarsia gemmatalis Hübner (Lepidoptera: Noctuidae) com base em análises em 
multivariadas. Neotrop. Entomol. 39 (2), 260-265. http://dx.doi. org/10.1590/S1519-566X2010000200018.

Piubelli, G. C., Hoffmann-Campo, C. B., Moscardi, F., Miyakubo, S. H., Oliveira, M. C. N., 2005. Are chemical compounds important for soybean resistance to Anticarsia gemmatalis?J. Chem. Ecol. 31 (7), 1509-1525. http://dx.doi.org/10.1007/s10886-005-5794-z.

Prado, J. C., Penaflor, M. F. G. V., Cia, E., Vieira, S. S., Silva, K. I., CarliniGarcia, L. A., Lourenção, A. L., 2016. Resistance of cotton genotypes with different leaf colour and trichome density to Bemisia tabaci biotype B. J. Appl. Entomol. 140 (6), 405-413. http://dx.doi. org/10.1111/jen.12274.

R Development Core Team, 2017. R: A Language and Environment for Statistical Computing. R Foundation for Statistical Computing, Vienna.

Santos, K. B., Meneguim, A. M., Neves, P. M. O. J., 2005. Biologia de Spodoptera eridania (Cramer) (Lepidoptera: Noctuidae) em diferentes hospedeiros. Neotrop. Entomol. 34 (6), 903-910. http:// dx.doi.org/10.1590/S1519-566X2005000600005.

Santos, K. B., Neves, P. J., Meneguim, A. M., Santos, R. B., Santos, W. J., Villas Boas, G., Dumas, V. E., Martins, E., Praça, L. B., Queiroz, P., Berry, C., Monnerat, R., 2009. Selection and characterization of th Bacillus thuringiensis strains toxic to Spodoptera eridania(Cramer), Spodoptera cosmiodes (Walker) and Spodoptera frugiperda(Smith) (Lepidoptera: noctuidae). BioControl 50, 157-163. https://doi. org/10.1016/j.biocontrol.2009.03.014.

Seifi, A., Visser, R. G. F., Bai, Y., 2013. How to effectively deploy plant resistances to pests and pathogens in crop breeding. Euphytica 190 (3), 321-334. http://dx.doi.org/10.1007/s10681-012-0823-9.

Silva, J. P. G. F., Baldin, E. L. L., Souza, E. S., Canassa, V. F., Lourenção, A. L., 2013. Characterization of antibiosis to the redbanded stink bug Piezodorus guildinii (Hemiptera:Pentatomidae) in soybean entries. J. Pest Sci. 86 (4), 649-657. http://dx.doi.org/10.1007/ s10340-013-0527-5.

Silva, J. P. G. F., Baldin, E. L. L., Canassa, V. F., Souza, E. S., Lourenção, A. L., 2014. Assessing antixenosis of soybean entries against Piezodorus guildinii (Hemiptera: pentatomidae). Arthropod-Plant Interact. 8, 349-359. http://dx.doi.org/10.1007/s11829-014-9316-1.

Silva, T. R. F. B., Almeida, A. C. S., Moura, T. L., Silva, A. R., Freitas, S. S., Jesus, F. G., 2016. Effect of the flavonoid rutin on the biology of Spodoptera frugiperda (Lepidoptera: noctuidae). Acta Sci. Agron. 38 (2), 165-170. http://dx.doi.org/10.4025/actasciagron.v38i2.27956.
Silveira, L. C. P., Vendramim, J. D., Rossetto, C. J., 1997. Efeito de genótipos de milho no desenvolvimento de Spodoptera frugiperda(J. E. Smith). An. Soc. Entomol. Bras. 26 (2), 291-298. http://dx.doi.org/10.1590/ S0301-80591997000200010.

Smith, C. M., 2005. Plant Resistance to Arthropods: Molecular and Conventional Approaches. Springer, Berlin, 423pp. http://dx.doi. org/10.1007/1-4020-3702-3.

Sosa-Gómez, D. R., López Lastra, C. C., Humber, R. A., 2010. An overview of arthropod associated fungi from Argentina and Brazil. Mycopathologia 170 (1), 61-76. http://dx.doi.org/10.1007/s11046-010-9288-3.

Sosa-Gómez, D. R., Silva, J. J., 2010. Neotropical brown stink bug (Euschistus heros) resistance to methamidophos in Paraná. Pesqui. Agropecu. Bras. 45 (7), 767-769. http://dx.doi.org/10.1590/S0100204X2010000700019.

Sousa, D. M. G., Lobato, E., 2004. Cerrado: correção do solo e adubação, 2a ed. Embrapa Informação Tecnológica, Brasília, DF, 416pp.

Souza, B. H. S., Costa, E. N., Silva, A. G., Boiça Junior, A. L., 2014a. Aspectos bionômicos de Spodoptera eridania(Cramer): uma praga em expansão na cultura da soja na região do cerrado brasileiro. EntomoBrasilis 7 (2), 75-80. http://dx.doi.org/10.12741/ebrasilis.v7i2.381.

Souza, B. H. S., Silva, A. G., Janini, J. C., Boica Júnior, A. L., 2014b. Antibiosis in soybean genotypes and the resistance levels to Spodoptera eridania(Cramer) (Lepidoptera: noctuidae). Neotrop. Entomol. 43 (6), 582-587. http://dx.doi.org/10.1007/s13744-014-0241-x.

Souza, P. V., Machado, B. R., Silva, D. C., Menezes, I. P. P., Araújo, M. S., Jesus, F. G., 2014c. Efect of resistance inducers and trichome on attraction of Euchistus heros (Hemiptera: Pentatomidae) to soybeans. Afr. J. Agric. Res. 9, 889-894. https://doi.org/10.5897/AJAR2013.8030.

Timbó, R. V., Hermes-Lima, M., Silva, L. P., Mehta, A., Moraes, M. C. B., Paula, D. P., 2014. Biochemical aspects of the soybean response to herbivory injury by the brown stink bug Euschistus heros(Hemiptera: pentatomidae). PLoS One 9(10), e109735. http://dx.doi.org/10.1371/ journal.pone.0109735.

War, A. R., Paulraj, M. G., Ahmad, T., Buhroo, A. A., Hussain, B., Ignacimuthu, S., Sharma, H. C., 2012. Mechanisms of plant defense against insect herbivores. Plant Signal. Behav. 7 (10), 1306-1320. http://dx.doi. org/10.4161/psb.21663. 